\title{
A RETROSPECTIVE OBSERVATIONAL STUDY ON RECEPTOR STATUS AND CO- MORBIDITIES OR HISTORY OF THYROID DISORDERS AND/OR GALLBLADDER STONES ASSOCIATED WITH BREAST CANCER PATIENTS.
}

\author{
DIVYA PANTHI ${ }^{1}$, ALIBHA RAWAT ${ }^{1}$, ASHA AGARWAL ${ }^{2}$, RUPA GUHA NANDI $^{2} \&$ N. GANESH $^{1}$ * \\ ${ }^{I}$ Department of Research, Jawaharlal Nehru Cancer Hospital and Research Centre, Idgah Hills, Bhopal \\ ${ }^{2}$ Department of Biotechnology, Sri Satya Sai College for Women, Habibganj, Bhopal
}

\begin{abstract}
Breast cancer is the commonest cancer found in females and has been increasing alarmingly in India since the last decade or so. In order to understand the risk factors associated with this disease, an observational retrospective study was done on total 110 registered breast cancer patients of the age group 18 to 65 from Jawaharlal Nehru Cancer Hospital and Research Centre (JNCHRC), Bhopal. Patients files from the hospital were analyzed in detail for clinical and pathological information including hormone receptor (HR) status. Medical history with a special focus on co-morbidities like thyroid disorders and gallbladder stone history was recorded. These two diseases have been linked to breast cancer development and the present observational study was aimed to throw light into this connection. Out of the 110 breast cancer patients, the receptor most prevalent was Er+ (39\%) followed by Her2+ (30\%) and Pr+ (26\%). There were 33\% triple negative cases and only $7 \%$ were triple positive. It was found that out of 110 breast cancer patients $59 \%$ had thyroid disorders and $32 \%$ had gall bladder disease/stones. A long-term large-scale population-based study is required to come to a firm conclusion to find a link so that aggressive measures could be taken to prevent cancer development in these high-risk categories of females.
\end{abstract}

KEYWORDS: Breast cancer, co-morbidities, gall bladder stones, receptor status, thyroid disorder.

Received: May 04, 2021; Accepted: May 24, 2021; Published: Jun 24, 2021; Paper Id.: IJBTRDEC20211

\section{INTRODUCTION}

Breast cancer is one of the most prevalent cancers in women and in Bhopal, Madhya Pradesh alone it has been increasing at an alarming rate. Some diseases have been linked with the development of breast cancer by various studies; notably, among them are thyroid disorder (thyroidism) and gallbladder stones (cholelithiasis). To find a link between these diseases and mechanism, a number of studies have been done in the last decade. The current research work aims to evaluate the possible association of thyroid disorders and gallbladder stones with carcinoma of breast. A number of breast cancer patients are found to have a history of thyroid problems and/or gallbladder stones indicating a possible role of these diseases in the development of breast cancer. Hyperthyroidism has been shown to pose a higher risk of breast cancer (Mette Søgaard et al., 2016). Similarly, studies have shown a link between gall bladder disease and breast cancer risk (Wysowski et al., 1986 and Shabanzadeh et al., 2017). Large population, lack of screening program or participation in screening program along with lack of awareness are the major reasons for high number of increased cases and high net mortality (Chauhan A, et al., 2011). What is alarming is the fact that more and more younger females of premenopausal age are getting afflicted with breast cancer (Agarwal G, 2007). Besides known risk factors that contribute to the disease, certain medical conditions are also linked with developing breast cancer. These are diabetes mellitus, thyroid disorders, gall bladder stones etc. A number of studies have been done to find an association between these diseases and development of breast cancer. The current retrospective observational study has been done to find a possible link between these medical conditions or co-morbidities as 
well as to record and analyze other clinico-pathological characters like receptor status commonly found in breast cancer females. The receptor status of breast cancer, including ER, PR and Her 2, play a crucial role in the development of treatment plan of breast cancer and these receptor status in breast cancer have been established as predictive, prognostic as well as therapeutic indicator. ER, PR and Her 2 receptor status are therapeutic targets for hormonal therapy. Therefore, it is important to note the prevalence of these receptors. Correlation between receptor status and age has been found according to certain studies. Also, a significant study has found correlation between estrogen receptor expression and co-morbidity found in breast cancer (de Decker L et al., 2014).

\section{MATERIALS AND METHODS}

Institutional Ethical Approval was taken for the study (IEC No: 779/IEC 225/JNCH/2020). This is a retrospective observational study of 110 breast cancer patients (age 18-70) whose details were recorded and analyzed from the medical records from JNCHRC, Idgah Hills after obtaining patient informed consent, Bhopal. Their demographic and clinicopathological details were recorded including receptor status, TNM and medical and surgical history. Special focus was given to receptor status and co-morbidities present in them. Statistical analysis was done.

\section{OBSERVATION AND RESULT}

Among the 110 breast cancer patients analyzed, 39\% were estrogen receptor (ER) positive, 26\% were progesterone receptor (PR) positive and 30\% were human epidermal growth factor receptor 2 (Her2) positive, 19\% were ER/PR positive and Her 2 negative, $7 \%$ were ER/PR/Her-2 positive and 33\% were ER/PR/Her-2 negative or triple negative as shown in Table 1. Another aspect was correlation of receptor status with age, it was found that older women were more likely to be hormone receptor (both ER and PR) (HR) positive than younger ones.

Table 1: Hormone Receptor Status of Enrolled Breast Cancer Patients

\begin{tabular}{|c|c|c|c|c|c|c|}
\hline $\begin{array}{c}\text { Total No of } \\
\text { Patients (N) }\end{array}$ & $\begin{array}{c}\text { ER+ } \\
\text { (in \%) }\end{array}$ & $\begin{array}{c}\text { PR+ } \\
\text { (in \%) }\end{array}$ & $\begin{array}{c}\text { Her2+ } \\
\text { (in \%) }\end{array}$ & $\begin{array}{c}\text { Triple + } \\
\text { (in \%) }\end{array}$ & $\begin{array}{c}\text { Triple - } \\
\text { (in \%) }\end{array}$ & $\begin{array}{c}\text { ER/PR+ } \\
\text { (HR+) }\end{array}$ \\
\hline $\mathbf{1 1 0}$ & $43(39 \%)$ & $29(26 \%)$ & $17(30 \%)$ & $8(7 \%)$ & $36(33 \%)$ & $21(19 \%)$ \\
\hline
\end{tabular}

Legends: ER: Estrogen Receptor, PR: Progesterone Receptor, Her2: Human epidermal receptor.

The status of receptors in breast cancer plays important role in the treatment plan as hormonal therapy can be given to receptor positive patients. Triple negative patients on the other hand are not responsive to hormonal therapy and have to be treated with chemotherapy.

As far as co-morbidities are concerned, out of 110 breast cancer patients 65 (59\%) had thyroid disorders and 35 (32\%) had gallbladder stones thus showing a strong association as shown in Table 2.

Table 2: Breast Cancer Patients with Co-Morbidity or History of Thyroid Issues or Gallbladder Stones

\begin{tabular}{|c|c|c|}
\hline $\begin{array}{c}\text { Total No of Breast Ca } \\
\text { Patients (N) }\end{array}$ & BGB & BTH \\
\hline 110 & $35(32 \%)$ & $\mathbf{6 5}(59 \%)$ \\
\hline & & \\
\hline
\end{tabular}

\section{Legends: BTH: Breast Ca patients with Thyroid disorders,}

BGB: Breast Ca patients with gall bladder stones 


\section{CONCLUSIONS}

Understanding the role that co-morbid conditions or history of certain medical conditions play in breast cancer development is important because co-morbidities influence decisions about treatment plan and are independent risk factors for survival. History of certain prevalent diseases can be indicative of their link or association with the carcinogenesis process. For example, the high prevalence of thyroid problems in breast cancer patients is indicative of its association with breast cancer development. Patients with gall bladder stones or a history of gall bladder stones were also prevalent (32\%) in the registered breast cancer patients. This is a preliminary study covering a small sample size. Large scale study needs to be done to come to a firm conclusion and to find a mechanism to understand the link between these diseases and their patho-physiology that may lead to breast cancer development. Besides these conditions, receptor status of breast cancer plays an important role in the treatment plan and is a clinically established parameter that is tested. It also influences the prognosis of a patient as supported by certain studies that have demonstrated that breast cancer patients with tumors that are estrogen receptor (ER)-positive and/or progesterone receptor (PR)-positive have lower risks of mortality after their diagnosis compared to women with ER- and/or PR-negative disease (Dunnwald et al.,2007). Thus, more studies need to be done to understand the role of receptor status in the prognosis of breast cancer.

\section{ACKNOWLEDGEMENT}

We are thankful to the management of JNCH\&RC, Idgah Hills, Bhopal for providing us with the facilities of the Research Lab, Hospital premises and registry office to carry out this research work and would like to acknowledge our deep sense of gratitude for the same.

\section{REFERENCES}

1. Banyameen lqbal, Archana Buch (2016): Hormone receptor (ER, PR, Her2) status and proliferation index marker (ki-67) in breast cancers: Their Onco-pathological correlation, shortcomings and future trends. Med J DY Patil Univ, 2018:9:674-9.

2. Nadham K. Mahdi, Hiba Qassem Ali \& Mohammed H. Al-Jawher, "How Useful is Urine Protein in the Diagnosis and Prognosis of Breast Cancer in Women? ", International Journal of Medicine and Pharmaceutical Science (IJMPS), Vol. 6, Issue 1,pp, 31- 36

3. Jessica M Engel, Robert T Greenlee (2009): Breast cancer subtypes based on ER/PR and Her2 Expression: Comparison of clinico-pathologic Features and survival. Clin Med Res. 2009;7(1-2):4-13

4. Lamyaa Kadhim Oudah, "A Study on the Prevalence of Breast Cancer in Women at Thi-Qar Province",International Journal of Medicine and Pharmaceutical Science (IJMPS), Vol. 6, Issue 1,pp, 119-124

5. Jennifer Robinson (2020): Types of breast cancer: breastcancer.org.' How to Read Hormone Receptor Test Results' Triple Negative Breast Cancer'.

6. Carol A. Parise, Vincent Caggiano (2014): Breast cancer Survival Defined by the ER/PR/Her2 Subtypes and a surrogate classification according to tumor grade and immunohistochemical biomarkers. Journal of Cancer Epidemiology. Vol 2014, 11 pages, 2014.

7. Hadeel Salim Alkutubi, "Regression Study for Breast Cancer in Al-Sader Medical City ”,International Journal of Applied Mathematics \& Statistical Sciences (IJAMSS), Vol. 2, Issue 3,pp, 1-6

8. Jiang X, Castelao JE, Chavez-Uribe E, Rodriguez BF, Muñoz CC, Redondo CM, et al., (2012). Family History and Breast Cancer Hormone Receptor Status in a Spanish Cohort. PLoS ONE 7(1): e29459. 
9. Laila I. Al-Daken \& Muayyad M. Ahmad, “Assessing Levels of Self-Efficacy among Family Caregivers of Patients with Cancer ",International Journal of Applied and Natural Sciences (IJANS), Vol. 7, Issue 2,pp; 91 - 98

10. Chu KC, Anderson WF (2002): Rates for breast cancer characteristics by estrogen and progesterone receptor status in the major racial/ethnic groups. Breast Cancer Res Treat. 2002;74:199-211.

11. Colditz GA, Rosner BA, Chen WY, Holmes MD, Hankinson SE.(2004): Risk factors for breast cancer according to estrogen and progesterone receptor status. J Natl Cancer Inst. 2004;96:218-228.

12. Setiawan VW, Monroe KR, Wilkens LR, Kolonel LN, Pike MC, et al., (2009): Breast Cancer Risk Factors Defined by Estrogen and Progesterone Receptor Status. American Journal of Epidemiology.2009; 169:1251-1259.

13. Sharma N, Narayan S, Sharma R, Kapoor A, Kumar N, Nirban R. Association of comorbidities with breast cancer: An observational study. Tropical Journal of Medical Research [Internet]. 2015;19:168-71.

14. Jitendra Singh Nigam, Poonam Yadav, and Neelam Sood. A retrospective study of clinico-pathological spectrum of carcinoma breast in West Delhi, India. South Asian J Cancer, 2014 Jul-Sep; 3(3): 179-181.

15. de Decker L, Campone M, Retornaz F, et al.,. Association between oestrogens receptor expressions in breast cancer and comorbidities: a cross-sectional, population-based study. PLoS One. 2014; 9(5):e98127.

16. Dunnwald LK, Rossing MA, Li CI. Hormone receptor status, tumor characteristics, and prognosis: a prospective cohort of breast cancer patients. Breast Cancer Res. 2007; 9 (1):R6.

17. Aman Chauhan, SH Subba*, Ritesh G Menezes, B Suresh Kumar Shetty, Vikrant Thakur, Sarabjeet Chabra, Raj Warrier. Younger Women are affected by Breast Cancer in South India - A Hospital-based Descriptive Study. Asian Pacific J Cancer Prev, 12, 709-711.

18. Agarwal G, Ramakant P. Breast Cancer Care in India: The Current Scenario and the Challenges for the Future. Breast Care (Basel). 2008; 3(1):21-27.

19. Mette Søgaard, Dora Kormendine Farkas, Vera Ehrenstein, Jens Otto Lunde Jørgensen, Olaf M. Dekkers and Henrik Toft Sørensen. Hypothyroidism and hyperthyroidism and breast cancer risk: a nationwide cohort study European Journal of Endocrinology (2016) 174, 409-414.

20. Wysowski DK, Goldberg EL, Comstock GW, Diamond EL. A study of a possible association between breast cancer and gallbladder disease. Am J Epidemiol. 1986 Mar;123(3):532-43.

21. Daniel Mønsted Shabanzadeh, Lars Tue Sørensen, and Torben Jørgensen. Association between Screen-Detected Gallstone Disease and Cancer in a Cohort Study. Gastroenterology 2017; 152: 1965-1974. 